\title{
Antibacterial activity and time kill kinetics of Amlodipine, Thioridazine and Promethazine against pathogenic clinical bacterial isolates
}

\author{
${ }^{* 1}$ Akinjogunla, O. J., ${ }^{2}$ Umo, A. N., ${ }^{3}$ Alozie, M. F., ${ }^{2}$ Oshosanya, G. O., and ${ }^{1}$ Saturday, G. I. \\ ${ }^{1}$ Department of Microbiology, University of Uyo, P.M.B. 1017, Uyo, Akwa Ibom State, Nigeria \\ 2Department of Medical Microbiology and Parasitology, Faculty of Clinical Sciences, University of Uyo, \\ Uyo, Akwa Ibom State, Nigeria \\ ${ }^{3}$ Department of Pharmaceutical Microbiology and Biotechnology, Faculty of Pharmacy, University of Uyo, \\ Uyo, Akwa Ibom State, Nigeria \\ *Correspondence to: papajyde2000@yahoo.com
}

\begin{abstract}
:
Background: The emergence of multi-drug resistant bacterial strains worldwide has necessitated the scientific search for novel, potent, and affordable antimicrobial agents including medicinal plants and non-antibiotic drugs for therapy of infectious diseases. The objective of this study is to assess in vitro antibacterial activities and time kill kinetics of some non-antibiotic drugs against pathogenic clinical bacterial isolates.

Methodology: In vitro antibacterial activities including minimum inhibitory concentration (MIC), minimum bactericidal concentration (MBC) and time kill kinetics of Amlodipine (AML), Thioridazine (THI) and Promethazine (PRO) against Staphylococcus aureus, coagulase negative staphylococci (CoNS), Streptococcus spp, Escherichia coli, Enterobacter spp, Klebsiella pneumoniae and Pseudomonas aeruginosa clinical isolates were determined using disc diffusion, broth microdilution and plate count techniques.

Results: The mean growth inhibition zones by the disc diffusion assay of AML, THI and PRO against the isolates were $\leq 15.1 \pm 1.0 \mathrm{~mm}$ with MIC and MBC values ranging from 12.5 to $50 \mu \mathrm{g} / \mathrm{ml}$ and 25 to $100 \mu \mathrm{g} / \mathrm{ml}$ respectively. The time-kill assay revealed bactericidal effect of AML, THI and PRO on Gram positive bacteria evidenced by mean log reductions in viable bacterial cell counts ranging from $0.13 \log _{10}$ to $2.41 \log _{10} \mathrm{CFU} / \mathrm{ml}$ for $S$. aureus, 0.88 Log 10 to $2.08 \log _{10} \mathrm{CFU} / \mathrm{ml}$ for Streptococcus spp, and $0.26 \log _{10}$ to $2.34 \log _{10} \mathrm{CFU} / \mathrm{ml}$ for CoNS after $\leq 30 \mathrm{hrs}$ post inoculation at $1 \times M I C$. The range of log reduction in viable cell counts of Gram-negative bacteria exposed to AML, THI and PRO were E. coli $\left(0.11\right.$ to $\left.3.23 \log _{10} \mathrm{CFU} / \mathrm{ml}\right), P$. aeruginosa $\left(0.52\right.$ to $\left.2.56 \log _{10} \mathrm{CFU} / \mathrm{ml}\right), \mathrm{K}$. pneumoniae (0.85 to $\left.3.0 \log _{10} \mathrm{CFU} / \mathrm{ml}\right)$ and Enterobacter spp $\left(0.38\right.$ to $\left.2.08 \log _{10} \mathrm{CFU} / \mathrm{ml}\right)$ after $\leq 30$ hrs post inoculation at $1 \mathrm{x}$ MIC.

Conclusion: These findings demonstrate in vitro antibacterial efficacies and time kill kinetics of AML, THI and PRO against pathogenic clinical bacterial isolates, which indicate that these non-antibiotic drugs may be useful therapeutic alternatives in the bid to reduce the burden of infectious diseases associated with antibiotic resistant pathogens.
\end{abstract}

Keywords: Amlodipine, Thioridazine, Promethazine, Time-Kill, Kinetics, MIC, MBC, bacteria

Received April 8, 2020; Revised July 12, 2020; Accepted July 13, 2020

Copyright 2021 AJCEM Open Access. This article is licensed and distributed under the terms of the Creative Commons Attrition 4.0 International License <a rel="license" href="http://creativecommons.org/licenses/by/4.0/", which permits unrestricted use, distribution and reproduction in any medium, provided credit is given to the original author(s) and the source. Editor-in-Chief: Prof. S. S. Taiwo

\section{Activité antibactérienne et cinétique de destruction du temps de l'amlodipine, de la thioridazine et de la prométhazine contre les isolats bactériens cliniques pathogènes}

\author{
${ }^{* 1}$ Akinjogunla, O. J., ${ }^{2}$ Umo, A. N., ${ }^{3}$ Alozie, M. F., ${ }^{2}$ Oshosanya, G. O., et ${ }^{1}$ Saturday, G. I. \\ ${ }^{1}$ Département de microbiologie, Université d'Uyo, P.M.B. 1017, Uyo, Akwa Ibom State, Nigéria \\ ${ }^{2}$ Département de microbiologie médicale et de parasitologie, Faculté des sciences cliniques, Université d'Uyo,
} Uyo, État d'Akwa Ibom, Nigéria 


\author{
${ }^{3}$ Département de microbiologie et biotechnologie pharmaceutiques, Faculté de pharmacie, \\ Université d'Uyo, Uyo, État d'Akwa Ibom, Nigéria \\ *Correspondance à: papajyde2000@yahoo.com
}

\title{
Abstrait:
}

Contexte: L'émergence de souches bactériennes multirésistantes dans le monde a rendu nécessaire la recherche scientifique d'agents antimicrobiens nouveaux, puissants et abordables, notamment des plantes médicinales et des médicaments non antibiotiques pour le traitement des maladies infectieuses. L'objectif de cette étude est d'évaluer les activités antibactériennes in vitro et la cinétique de destruction temporelle de certains médicaments non antibiotiques contre les isolats bactériens cliniques pathogènes.

Méthodologie: activités antibactériennes in vitro, y compris la concentration minimale inhibitrice (CMI), la concentration bactéricide minimale $(M B C)$ et la cinétique de destruction du temps de l'amlodipine (AML), de la thioridazine (THI) et de la prométhazine (PRO) contre Staphylococcus aureus, les staphylocoques à coagulase négative (CoNS), Streptococcus spp, Escherichia coli, Enterobacter spp, Klebsiella pneumoniae et Pseudomonas aeruginosa ont été déterminés en utilisant des techniques de diffusion sur disque, de microdilution en bouillon et de numération sur plaque.

Résultats: Les zones moyennes d'inhibition de la croissance par le test de diffusion de disque d'AML, THI et PRO contre les isolats étaient $\leq 15,1 \pm 1,0 \mathrm{~mm}$ avec des valeurs MIC et MBC allant de 12,5 à $50 \mu \mathrm{g} / \mathrm{ml}$ et de 25 à $100 \mu \mathrm{g} / \mathrm{ml}$ respectivement. Le dosage temporel a révélé un effet bactéricide de la LMA, du THI et du PRO sur les bactéries Gram positives, mis en évidence par des réductions logarithmiques moyennes du nombre de cellules bactériennes viables allant de $0,13 \log 10$ à $2,41 \mathrm{Log} 10 \mathrm{CFU} / \mathrm{ml}$ pour $S$. aureus, 0,88 Log10 à 2,08 Log $10 \mathrm{CFU} / \mathrm{ml}$ pour Streptococcus spp et $0,26 \log 10$ à 2,34 Log10 CFU/ml pour CoNS après $\leq 30$ heures après l'inoculation à $1 \times$ MIC. La plage de réduction logarithmique du nombre de cellules viables de bactéries à Gram négatif exposées à la LMA, au THI et au PRO était $E$. coli $(0,11$ à $3,23 \log 10 \mathrm{CFU} / \mathrm{ml}), P$. aeruginosa $(0,52$ à 2,56 Log $10 \mathrm{CFU} / \mathrm{ml}), \mathrm{K}$. pneumoniae $(0,85$ à 3,0 Log $10 \mathrm{CFU} / \mathrm{ml})$ et Enterobacter spp $(0,38$ à $2,08 \mathrm{Log} 10 \mathrm{CFU} / \mathrm{ml})$ après $\leq 30$ heures après l'inoculation à $1 \times$ MIC.

Conclusion: Ces résultats démontrent une efficacité antibactérienne in vitro et une cinétique de destruction du temps des LMA, THI et PRO contre les isolats bactériens cliniques pathogènes, ce qui indique que ces médicaments non antibiotiques peuvent être des alternatives thérapeutiques utiles dans le but de réduire le fardeau des maladies infectieuses associées aux antibiotiques pathogènes résistants.

Mots-clés: Amlodipine, Thioridazine, Prométhazine, Time-Kill, Cinétique, MIC, MBC, bactéries

\section{Introduction:}

Although the pharmaceutical industries are still in the business of producing new antibiotics for treatment of infectious diseases, the numbers of infections caused by resistant microorganisms continue to increase owing to combinations of microbial characteristics and selective pressure created by antimicrobial use $(1,2)$. The mechanisms of microbial resistance to antimicrobial agents include the production of structure-inactivating enzymes, alteration of cell wall, cell membrane and enzyme (e.g. DNA gyrase) target sites and ribosomal modification (3). The emergence of multi-drug resistant (MDR) microbial strains has necessitated the scientific search for potent, novel and affordable antimicrobial agents including plants $(4,5)$ and non-antibiotic drugs for the treatment of infectious diseases.

Scores of non-antibiotic drugs, pharmaceutical preparations belonging to different pharmacological classes, currently used in the treatment of non-infectious diseases have been reported to exhibit both in vitro and in vivo antimicrobial activities (6). The non-antibiotic drugs, which inhibit microbial metabolism (7), with either biocidal or biostatic activity include anti-psychotics (thioridazine, clozapine), antihypertensives (nifedipine and amlodipine) (8), non-steroidal anti-inflammatory drugs (ibuprofen, diclofenac sodium) (9), pump inhibitors (esomeprazole, omeprazole), anti-histamines (promethazine, trimeprazine) (10), and antidepressants (sertraline and paroxetine) (11).

Promethazine is usually administered to attenuate inflammatory process in disease conditions such as allergic rhinitis, conjunctivitis, and urticaria $(12,13)$. The use of antihistamines, especially the first-generation phenothiazine $\mathrm{H} 1$-inhibitors such as promethazine for patients with microbial infection may become inevitable and this has prompted the evaluation of their antimicrobial properties.

The antibacterial activity of amlodipine, a cardiovascular drug, was reported by Kumar et al., (8) on several clinical bacterial isolates including Staphylococcus aureus, Escherichia coli, Vibrio spp, Salmonella spp, Bacillus spp and Pseudomonas aeruginosa. Similarly, in addition to the antipsychotic properties of thioridazine, significant antimicrobial activities against intracellular microorganisms have been reported (14). The objective of this study is to 
determine the antibacterial activities and time kill kinetics of amlodipine, thioridazine and promethazine against selected pathogenic clinical bacterial isolates.

\section{Materials and method:}

\section{Identification of bacterial isolates}

Fourteen (14) clinical bacterial isolates comprising Staphylococcus aureus $(n=2)$, coagulase negative staphylococci $(n=2)$, Streptococcus spp $(n=2)$, Escherichia coli $(n=2)$, Klebsiella pneumoniae $(\mathrm{n}=2)$, Enterobacter $\operatorname{spp}(\mathrm{n}=$ $2)$, and Pseudomonas aeruginosa $(n=2)$ were obtained from the Department of Microbiology, University of Uyo, Akwa Ibom State, Nigeria. These bacteria were isolated from clinical specimens and identified using conventional morphological and biochemical tests (15).

Source of the non-antibiotic drugs (Amlodipine, Thioridazine and Promethazine)

Amlodipine (AML, MAF India Pharmaceutical, India), Thioridazine (THI, Indian Generic Company, India) and Promethazine (PRO, CSC Pharmaceuticals International, India) were purchased in tablet forms from registered Pharmacy stores in Uyo. Stock solution of each drug was prepared by dissolving $1 \mathrm{~g}$ of each in $100 \mathrm{ml}$ of sterile distilled water to give a concentration of $10 \mathrm{mg} / \mathrm{ml}$. The stock solution was further diluted to produce $5 \mathrm{mg} / \mathrm{ml}$ and 2.5 $\mathrm{mg} / \mathrm{ml}$ concentrations for each of AML, THI and PRO.

Determination of antibacterial activity of the non-antibiotic drugs by disc diffusion assay

The antibacterial activities of AML, THI and PRO on the clinical bacterial isolates were determined by the disc diffusion method (16). Paper discs of AML, THI and PRO were prepared by punching sterile Whatman filter paper (No.1) with a $6 \mathrm{~mm}$ disc puncher and sterilizing them at $160^{\circ} \mathrm{C}$ for one hour. Each disc was then impregnated with $10 \mu \mathrm{L}$ of $2.5 \mathrm{mg} / \mathrm{ml}$ and $5.0 \mathrm{mg} / \mathrm{ml}$ concentrations of $\mathrm{AML}, \mathrm{THI}$ and PRO to give disc contents of $25 \mu \mathrm{g}$ and $50 \mu \mathrm{g}$ respectively.

Mueller-Hinton agar (MHA) plates were aseptically prepared and $0.1 \mathrm{ml}$ of each bacterial inoculum, prepared directly from an overnight nutrient agar plate and adjusted to 0.5 McFarland standards, was inoculated using sterile pipette onto each of the MHA plate. The impregnated discs were carefully placed on the MHA plates and incubated aerobically at $37^{\circ} \mathrm{C}$ for 24 hours followed by measurement of the diameters of zone of inhibition (in millimetres) using a calibrated ruler. The disc diffusion assays were performed in triplicates and the mean diameters of zones of inhibition were recorded.

Determination of minimum inhibitory (MIC) and minimum bactericidal concentration (MBC)

The MICs of AML, THI and PRO against the bacterial isolates were determined using macrobroth dilution technique in test tubes (5). One $\mathrm{ml}$ of the stock solution $(10 \mathrm{mg} / \mathrm{ml})$ of $A M L$, THI and PRO was serially diluted in test tubes to obtain concentrations of $5,2.5,1.25$ and $0.625 \mathrm{mg} / \mathrm{ml}$ for each of the non-antibiotic solution. To $0.1 \mathrm{ml}(100 \mu \mathrm{L})$ of each of these concentrations was added $9.9 \mathrm{ml}$ nutrient broth (1 in 100 dilution) to give the final concentrations of AML, THI and PRO of 100, 50, 25, 12.5 and $6.25 \mu \mathrm{g} / \mathrm{ml}$ for the MIC testing. A loopful of prepared inoculum of each bacterium was added to each of the non-antibiotic solution. A tube containing only nutrient broth was inoculated with bacterial isolate to serve as control. All culture tubes were incubated aerobically at $37^{\circ} \mathrm{C}$ for 24 hours, after which the tubes were examined for microbial growth by observing for turbidity. The MIC was read as the least concentration of the non-antibiotic solution that visibly inhibited the growth of the test bacterial isolate after 24 hours incubation.

For the MBC, an aliquot of $1 \mathrm{ml}$ from each of the MIC broth tubes that showed no visible growth was streak-inoculated onto sterile nutrient agar plates using a sterile pipette. The inoculated plates were inverted and incubated at $37^{\circ} \mathrm{C}$ aerobically for 24 hours. The MBC values of AML, THI and PRO were considered as the concentration of each nonantibiotic solution that resulted in killing of the bacterial isolates, which showed as no visible colonies on the agar plates.

\section{Time-kill analysis}

The time-kill analysis was carried out using macrobroth dilution and pour plate techniques. An overnight nutrient broth culture of each bacterial isolate in test tube was adjusted to 0.5 McFarland turbidity standard to obtain a starting inoculum of between $10^{5}$ and $10^{6} \mathrm{CFU} / \mathrm{ml}$ (confirmed by quantitative plate counts). The tubes were incubated at $37^{\circ} \mathrm{C}$ with shaken at $150 \mathrm{rpm}$ for 90 mins to ensure that microbial growths were in the logarithmic (exponential) phase. One (1) millilitre of this exponentially growing bacterial cultures was added to $9 \mathrm{ml}$ of MHB containing MIC concentration (1ml) of AML, THI and PRO. Bacterial growth was quantified at time ' 0 ' hour and at 
$6,12,18,24$, and 30 hours of incubation by aseptically taking $1 \mathrm{ml}$ of the aliquot, diluting serially (10-fold dilutions) in sterile normal saline and plating out $1 \mathrm{ml}$ of the final dilution onto nutrient agar plates. The plates were incubated aerobically for 24 hours at $37^{\circ} \mathrm{C}$ after which the colonies on each plate were enumerated and viable cells expressed as CFU/ml. Inoculated medium without $\mathrm{AML}, \mathrm{THI}$ and $\mathrm{PRO}$ was also set up and plated on nutrient agar as control. All experiments were performed in triplicates.

The percentage and logarithm reductions of the bacterial cells exposed to AML, THI and PRO were calculated for each of the time intervals. The $\log _{10} \mathrm{CFU} / \mathrm{ml}$ of survived bacterial cells against exposure time (in hours) were plotted on a semi-logarithm graph for each bacterial pathogen to obtain the time-kill curve. Activity of the non-antibiotic drugs was considered bactericidal at the lowest concentration that reduced the initial inoculum by $>3 \log _{10} \mathrm{CFU} / \mathrm{ml}$ (99.9\% killing). The percentage and logarithm reductions of the bacterial cells exposed to AML, THI and PRO were respectively calculated as; percentage reduction $=$ (initial counts - counts at ' $x$ ' interval)/ initial counts (multiply by 100), while the logarithm reduction $=\log _{10}$ (initial counts) $\log _{10}$ (counts at ' $\mathrm{x}$ ' interval).

\section{Statistical analysis}

All experiments were performed in triplicates and data analysis was done with the Statistical Package for the Social Sciences (SPSS) version 20.0. Data were presented as mean $\pm S D$ and comparison between mean values was done using the Duncan multiple range test, with significance level at $p<0.05$.

\section{Results:}

The mean growth inhibitory zone of AML against Gram-positive bacteria (GPB) ranged from $10.1 \pm 0.2 \mathrm{~mm}$ ( $25 \mu \mathrm{g}$ disk) to 13.6 $\pm 0.5 \mathrm{~mm}$ ( $50 \mu \mathrm{g}$ disk), and against Gram-negative bacteria (GNB), from 10.8 $0.2 \mathrm{~mm}$ ( $25 \mu \mathrm{g}$ disk) to $14.5 \pm 0.5 \mathrm{~mm}$ ( $50 \mu \mathrm{g}$ disk). The mean growth inhibitory zone of THI against GPB ranged from $8.8 \pm 0.1 \mathrm{~mm}$ ( $25 \mu \mathrm{g}$ disk) to 14.1 $\pm 0.5 \mathrm{~mm}$ ( $50 \mu \mathrm{g}$ disk) and against GNB, from $10.2 \pm 0.2 \mathrm{~mm}(25 \mu \mathrm{g}$ disk) to $14.7 \pm 1.0 \mathrm{~mm}$ (50 $\mu \mathrm{g}$ disk). For PRO, the mean growth inhibitory zone ranged from $9.3 \pm 0.1 \mathrm{~mm}$ ( $25 \mu \mathrm{g}$ disk) to $14.5 \pm 0.3 \mathrm{~mm}(50 \mu \mathrm{g}$ disk) against GPB, and 8.3

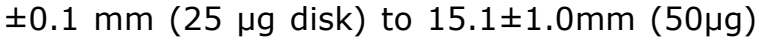
against GNB. The mean growth inhibitory zone of the levofloxacin control disk $(30 \mu \mathrm{g})$ was

Table 1: Antibacterial activities of non-antibiotic drugs on bacterial pathogens with disk diffusion method

\begin{tabular}{|c|c|c|c|c|c|c|c|c|}
\hline \multirow{3}{*}{ Bacterial Isolates } & \multirow{3}{*}{$\begin{array}{l}\text { Isolates } \\
\text { Code }\end{array}$} & \multicolumn{6}{|c|}{ Zone of Inhibition in mm (mean \pm SD) } & \multirow{3}{*}{$\begin{array}{c}\text { Control } \\
\text { (Levofloxacin) } \\
\text { (30 g disk) }\end{array}$} \\
\hline & & \multicolumn{2}{|c|}{ Amlodipine } & \multicolumn{2}{|c|}{ Thioridazine } & \multicolumn{2}{|c|}{ Promethazine } & \\
\hline & & $\begin{array}{c}2.5 \mathrm{mg} / \mathrm{ml} \\
(25 \mu \mathrm{g} \text { disk) }\end{array}$ & $\begin{array}{c}5 \mathrm{mg} / \mathrm{ml} \\
\text { (50ug disk) }\end{array}$ & $\begin{array}{l}2.5 \mathrm{mg} / \mathrm{ml} \\
(25 \mu \mathrm{g} \text { disk) }\end{array}$ & $\begin{array}{c}5 \mathrm{mg} / \mathrm{ml} \\
\text { (50ug disk) }\end{array}$ & $\begin{array}{l}2.5 \mathrm{mg} / \mathrm{ml} \\
(25 \mu \mathrm{gdisk})\end{array}$ & $\begin{array}{l}5 \mathrm{mg} / \mathrm{ml} \\
\text { (50ug disk) }\end{array}$ & \\
\hline Staphylococcus aureus & SA01 & $11.2 \pm 0.1^{a}$ & $13.6 \pm 0.5^{b}$ & $11.6 \pm 0.1^{\mathrm{a}}$ & $14.1 \pm 0.5^{b}$ & $12.3 \pm 0.2^{b}$ & $14.5 \pm 0.3^{b}$ & $13.6 \pm 0.3^{a}$ \\
\hline Staphylococcus aureus & $\mathrm{SAO2}$ & NZ & $9.8 \pm 0.2^{\mathrm{a}}$ & NZ & $9.3 \pm 0.1^{a}$ & NZ & NZ & NZ \\
\hline CoNS & $\mathrm{CSO} 2$ & NZ & $10.2 \pm 0.1^{a}$ & $9.0 \pm 0.1^{a}$ & $13.6 \pm 0.4^{b}$ & $9.3 \pm 0.1^{a}$ & $13.0 \pm 0.2^{b}$ & $14.5 \pm 0.5^{a}$ \\
\hline CoNS & $\mathrm{CS} 01$ & NZ & $12.4 \pm 0.3^{b}$ & $11.2 \pm 0.3^{a}$ & $14.0 \pm 0.2^{b}$ & NZ & $11.6 \pm 0.2^{a}$ & $14.0 \pm 0.1^{a}$ \\
\hline Streptococcus spp & SSO1 & $10.1 \pm 0.2^{\mathrm{a}}$ & $13.0 \pm 0.5^{b}$ & $10.0 \pm 0.1^{a}$ & $12.7 \pm 0.2^{b}$ & $10.4 \pm 0.2^{\mathrm{a}}$ & $12.1 \pm 0.5^{b}$ & $15.6 \pm 0.3^{b}$ \\
\hline Streptococcus spp & $\mathrm{SSO2}$ & NZ & $9.1 \pm 0.1^{\mathrm{a}}$ & $8.8 \pm 0.1^{a}$ & $10.4 \pm 0.1^{a}$ & $9.6 \pm 0.1^{a}$ & $11.2 \pm 0.1^{\mathrm{a}}$ & $14.3 \pm 0.2^{\mathrm{a}}$ \\
\hline Escherichia coli & ECO1 & $12.9 \pm 0.3^{b}$ & $14.5 \pm 0.5^{c}$ & $10.5 \pm 0.2^{b}$ & $13.1 \pm 0.3^{b}$ & $11.3 \pm 0.3^{\mathrm{a}}$ & $13.9 \pm 0.5^{b}$ & $15.1 \pm 0.5^{b}$ \\
\hline Escherichia coli & $\mathrm{ECO2}$ & $12.2 \pm 0.1^{b}$ & $14.0 \pm 0.3^{b}$ & $11.9 \pm 0.1^{a}$ & $13.8 \pm 0.3^{b}$ & $11.5 \pm 0.2^{\mathrm{a}}$ & $13.0 \pm 0.5^{b}$ & NZ \\
\hline Klebsiella pneumoniae & KP01 & NZ & $10.9 \pm 0.5^{a}$ & $10.2 \pm 0.2^{a}$ & $11.5 \pm 0.1^{\mathrm{a}}$ & NZ & $12.4 \pm 0.2^{b}$ & NZ \\
\hline Klebsiella pneumoniae & KPO2 & $11.5 \pm 0.5^{\mathrm{a}}$ & $13.7 \pm 1.0^{b}$ & $12.1 \pm 0.5^{b}$ & $14.7 \pm 1.0^{c}$ & $11.0 \pm 0.5^{\mathrm{a}}$ & $12.9 \pm 0.5^{b}$ & $16.0 \pm 1.0^{b}$ \\
\hline Enterobacter spp & $\mathrm{ESO2}$ & $12.0 \pm 0.2^{b}$ & $14.4 \pm 1.0^{b}$ & $12.6 \pm 0.5^{b}$ & $14.7 \pm 0.5 c$ & $12.6 \pm 0.2^{b}$ & $15.1 \pm 1.0^{c}$ & $16.5 \pm 0.5^{b}$ \\
\hline Enterobacter spp & ESO1 & $10.8 \pm 0.2^{\mathrm{a}}$ & $12.9 \pm 0.2^{b}$ & $10.8 \pm 0.1^{a}$ & $13.3 \pm 0.2^{b}$ & NZ & $11.3 \pm 0.2^{\mathrm{a}}$ & NZ \\
\hline Pseudomonas aeruginosa & PA01 & $12.4 \pm 0.5^{b}$ & $13.6 \pm 0.5^{b}$ & $11.6 \pm 0.2^{a}$ & $12.9 \pm 0.3^{b}$ & $12.1 \pm 0.2^{b}$ & $13.7 \pm 0.5^{b}$ & $14.8 \pm 0.5^{\mathrm{a}}$ \\
\hline Pseudomonas aeruginosa & PA02 & NZ & $8.6 \pm 0.1^{\mathrm{a}}$ & NZ & $9.5 \pm 0.1^{\mathrm{a}}$ & $8.3 \pm 0.1^{\mathrm{a}}$ & $10.9 \pm 0.2^{\mathrm{a}}$ & $12.0 \pm 0.3^{a}$ \\
\hline
\end{tabular}

CONS = Coagulase negative staphylococci; SD = Standard deviation; NZ = No inhibitory zone. Each value represents the mean plus standard deviation of three replicates. Mean within the column followed by different superscript letters are significant by Duncan's multiple range test $(p<0.05)$ 
Table 2: Minimum inhibitory and minimum bactericidal concentrations of non-antibiotic drugs against bacterial pathogens

\begin{tabular}{|c|c|c|c|c|}
\hline \multirow{2}{*}{$\begin{array}{l}\text { Bacterial } \\
\text { Isolates }\end{array}$} & \multirow{2}{*}{$\begin{array}{l}\text { Isolate } \\
\text { Codes }\end{array}$} & \multicolumn{2}{|c|}{$\mathrm{MIC} / \mathrm{MBC}(\mu \mathrm{g} / \mathrm{ml})$} & \multirow[b]{2}{*}{ PRO } \\
\hline & & AML & THI & \\
\hline Staphylococcus aureus & SA01 & $12.5 / 25$ & $12.5 / 25$ & $12.5 / 25$ \\
\hline Staphylococcus aureus & $\mathrm{SAO} 2$ & $50 />50$ & $50 />50$ & $>50 / 100$ \\
\hline CoNS & $\mathrm{CSO} 2$ & $50 />50$ & $25 / 50$ & $25 / 50$ \\
\hline CoNS & CSO1 & $50 / 50$ & $12.5 / 25$ & $50 / 50$ \\
\hline Streptococcus spp & SS01 & $25 / 50$ & $25 / 50$ & $12.5 / 50$ \\
\hline Streptococcus spp & $\mathrm{SSO} 2$ & $50 />50$ & $25 />50$ & $25 />50$ \\
\hline Escherichia coli & $\mathrm{ECO} 1$ & $12.5 / 50$ & $25 />50$ & $12.5 / 50$ \\
\hline Escherichia coli & $\mathrm{ECO} 2$ & $12.5 / 25$ & $12.5 / 25$ & $12.5 / 25$ \\
\hline Klebsiella pneumoniae & KPO1 & $50 / 50$ & $25 / 50$ & $50 />50$ \\
\hline Klebsiella pneumoniae & KPO2 & $25 />50$ & $12.5 / 25$ & $25 / 50$ \\
\hline Enterobacter spp & ESO2 & $12.5 / 25$ & $12.5 / 25$ & $12.5 / 50$ \\
\hline Enterobacter spp & ESO1 & $25 />50$ & $25 / 50$ & $50 />50$ \\
\hline Pseudomonas aeruginosa & PA01 & $12.5 />50$ & $12.5 / 50$ & $12.5 / 25$ \\
\hline Pseudomonas aeruginosa & PAO2 & $50 />50$ & $50 />50$ & $25 / 50$ \\
\hline
\end{tabular}

$13.6 \pm 0.3$ to $15.6 \pm 0.3 \mathrm{~mm}$ against $G P B$, and $12.0 \pm 0.3$ to $16.5 \pm 0.5 \mathrm{~mm}$ against GNB (Table $1)$.

The AML, THI and PRO inhibited the growth of all the 14 isolates tested with MIC values in the range of $12.5-50 \mu \mathrm{g} / \mathrm{ml}, 12.5-$ $50 \mu \mathrm{g} / \mathrm{ml}$ and $12.5->50 \mu \mathrm{g} / \mathrm{ml}$ respectively. The MIC values of THI were lowest for $S$. aureus, $E$. coli, K. pneumoniae, Enterobacter spp, $P$. aeruginosa and CoNS. The MBC values of AML, THI and PRO were in the range of $25-100 \mu \mathrm{g} /$ $\mathrm{ml}$. The MBC of AML for $78.6 \%$ of the bacterial isolates tested was $50 \mu \mathrm{g} / \mathrm{ml}$, the MBC of THI for $35.7 \%$ of bacterial isolates tested was $25 \mu \mathrm{g} / \mathrm{ml}$ while the MBC of PRO for $7.1 \%$ of the bacterial isolates tested was $100 \mu \mathrm{g} / \mathrm{ml}$ (Table 2). The results also indicated that both MIC and $\mathrm{MBC}$ end points obtained by visual reading for AML on CoNS and $K$. pneumoniae were equal.

The bactericidal activity was deemed to be present if there was a $\geq 99.9 \%$ reduction in survival from the original inoculum ( $\geq 99.9 \%$ killing). Table 3 showed the percentage and log reductions in GPB cells exposed to $A M L$, THI and PRO at 6 hours intervals after incubation. The percentage and log reduction in viable cell counts of $S$. aureus exposed to AML ranged from 33.3 to $\geq 99.9 \%$ and 0.18 to $2.41 \log _{10}$ $\mathrm{CFU} / \mathrm{ml}$ after $30 \mathrm{hrs}$ of interaction respectively while the percentage and log reduction in viable cell counts of Streptococcus spp exposed to AML ranged from 86.96 to $\geq 99.9 \%$ and 0.88 to $2.08 \log _{10} \mathrm{CFU} / \mathrm{ml}$ after 30 hours of interaction respectively.

The lowest percentage and logarithm

Table 3: Percentage and logarithm reductions in Gram positive bacterial cells exposed to non-antibiotic drugs

\begin{tabular}{|c|c|c|c|c|c|c|c|c|c|c|}
\hline \multirow[b]{2}{*}{$\begin{array}{l}\text { Isolate } \\
\text { Codes }\end{array}$} & \multirow[b]{2}{*}{$\begin{array}{l}\text { Exposed } \\
\text { Time (hr) }\end{array}$} & \multicolumn{3}{|c|}{ Amlodipine } & \multicolumn{3}{|c|}{ Thioridazine } & \multicolumn{3}{|c|}{ Promethazine } \\
\hline & & $\begin{array}{c}\mathrm{PC} \\
(\mathrm{CFU} / \mathrm{ml})\end{array}$ & $\begin{array}{l}\log _{10} \\
\text { CFU/ml }\end{array}$ & $\begin{array}{c}\% / \log \\
\text { Reduction }\end{array}$ & $\begin{array}{c}\mathrm{PC} \\
(\mathrm{CFU} / \mathrm{ml})\end{array}$ & $\begin{array}{l}\log _{10} \\
\mathrm{CFU} / \mathrm{ml}\end{array}$ & $\begin{array}{c}\% / \text { Log } \\
\text { Reduction }\end{array}$ & $\begin{array}{c}\mathrm{PC} \\
(\mathrm{CFU} / \mathrm{ml})\end{array}$ & $\begin{array}{c}\log _{10} \\
\mathrm{CFU} / \mathrm{ml}\end{array}$ & $\begin{array}{c}\% / \log \\
\text { Reduction }\end{array}$ \\
\hline \multirow{6}{*}{ SA01 } & 0 & $3.2 \times 10^{5}$ & 5.51 & $\mathrm{NA} / \mathrm{NA}$ & $3.6 \times 10^{5}$ & 5.56 & NA /NA & $3.2 \times 10^{5}$ & 5.51 & NA / NA \\
\hline & 6 & $4.5 \times 10^{4}$ & 4.65 & $33.33 / 0.18$ & $2.4 \times 10^{4}$ & 4.38 & $93.33 / 1.18$ & $4.5 \times 10^{4}$ & 4.65 & $85.90 / 0.86$ \\
\hline & 12 & $1.3 \times 10^{3}$ & 3.11 & $91.67 / 1 / 08$ & $2.2 \times 10^{3}$ & 3.34 & $90.83 / 1.04$ & $1.3 \times 10^{3}$ & 3.11 & $97.11 / 1.54$ \\
\hline & 18 & $2.7 \times 10^{2}$ & 2.43 & $83.50 / 0 / 78$ & $1.7 \times 10^{2}$ & 2.23 & $92.27 / 1.11$ & $2.7 \times 10^{2}$ & 2.43 & $79.23 / 0.68$ \\
\hline & 24 & $2.0 \times 10^{2}$ & 2.30 & $92.12 / 1.10$ & NG & 0.0 & $\geq 99.9 / 2.23$ & $2.0 \times 10^{2}$ & 2.30 & $25.93 / 0.13$ \\
\hline & 30 & $1.2 \times 10^{2}$ & 2.08 & $\geq 99.9 / 2.41$ & NG & 0.0 & $\geq 99.9 / 0.0$ & $1.2 \times 10^{2}$ & 2.08 & $40.00 / 0.22$ \\
\hline \multirow{6}{*}{$\mathrm{SSO2}$} & 0 & $3.6 \times 10^{5}$ & 5.56 & NA / NA & $4.8 \times 10^{5}$ & 5.68 & $\mathrm{NA} / \mathrm{NA}$ & $5.5 \times 10^{5}$ & 5.74 & NA / NA \\
\hline & 6 & $2.3 \times 10^{4}$ & 4.36 & $93.61 / 1.20$ & $2.4 \times 10^{4}$ & 4.38 & $95.0 / 1.30$ & $2.4 \times 10^{4}$ & 4.38 & $95.64 / 1.36$ \\
\hline & 12 & $3.0 \times 10^{3}$ & 3.48 & $86.96 / 0.88$ & $1.0 \times 10^{3}$ & 3.00 & $95.83 / 1.38$ & $3.3 \times 10^{3}$ & 3.52 & $86.25 / 0.86$ \\
\hline & 18 & $1.2 \times 10^{2}$ & 2.08 & $96.00 / 1.40$ & $1.2 \times 10^{2}$ & 2.08 & $88.00 / 0.92$ & $2.2 \times 10^{2}$ & 2.34 & $93.33 / 1.18$ \\
\hline & 24 & $\mathrm{NG}$ & 0.0 & $\geq 99.9 / 2.08$ & $\mathrm{NG}$ & 0.0 & $\geq 99.9 / 2.08$ & $1.2 \times 10^{2}$ & 2.08 & $45.50 / 0.26$ \\
\hline & 30 & NG & 0.0 & $\geq 99.9 / 0.0$ & NG & 0.0 & $\geq 99.9 / 0.0$ & $N G$ & 0.0 & $\geq 99.9 / 2.08$ \\
\hline \multirow{6}{*}{$\mathrm{CSO} 2$} & 0 & $4.8 \times 10^{5}$ & 5.68 & NA / NA & $3.6 \times 10^{5}$ & 5.56 & NA / NA & $3.6 \times 10^{5}$ & 5.56 & NA / NA \\
\hline & 6 & $3.6 \times 10^{4}$ & 4.56 & $92.50 / 1.12$ & $7.2 \times 10^{4}$ & 4.86 & $80.0 / 0.70$ & $2.0 \times 10^{5}$ & 5.30 & $44.44 / 0.26$ \\
\hline & 12 & $2.9 \times 10^{3}$ & 3.46 & $91.94 / 1.10$ & $5.3 \times 10^{3}$ & 3.72 & $92.64 / 1.14$ & $3.6 \times 10^{4}$ & 4.56 & $82.00 / 0.74$ \\
\hline & 18 & $1.2 \times 10^{3}$ & 3.08 & $58.62 / 0.38$ & $3.0 \times 10^{3}$ & 3.48 & $43.40 / 0.24$ & $2.0 \times 10^{3}$ & 3.30 & $94.44 / 1.26$ \\
\hline & 24 & $2.0 \times 10^{2}$ & 2.30 & $83.33 / 0.78$ & $2.2 \times 10^{2}$ & 2.34 & $92.67 / 1.14$ & $1.6 \times 10^{2}$ & 2.20 & $92.00 / 1.10$ \\
\hline & 30 & NG & 0.0 & $\geq 99.9 / 2.30$ & NG & 0.0 & $\geq 99.9 / 2.34$ & NG & 0.0 & $\geq 99.9 / 2.20$ \\
\hline
\end{tabular}

SA01 = Staphylococcus aureus; $\mathrm{SSO2}=$ Streptococcus spp; CSO2 = Coagulase negative staphylococcus; PC = Plate Counts; CFU = Colony Forming Units; $\mathrm{ml}=$ Millilitre; NG = No Growth; NA = Not Available 
Table 4: Percentage and logarithm reductions in Gram negative bacterial cells exposed to non-antibiotic drugs

\begin{tabular}{|c|c|c|c|c|c|c|c|c|c|c|}
\hline \multirow[b]{2}{*}{$\begin{array}{l}\text { Isolate } \\
\text { Codes }\end{array}$} & \multirow[b]{2}{*}{$\begin{array}{l}\text { Exposed } \\
\text { Time (hr) }\end{array}$} & \multicolumn{3}{|c|}{ Amlodipine } & \multicolumn{3}{|c|}{ Thioridazine } & \multicolumn{3}{|c|}{ Promethazine } \\
\hline & & $\begin{array}{c}\text { PC } \\
(\mathrm{CFU} / \mathrm{ml})\end{array}$ & $\begin{array}{l}\log _{10} \\
\text { CFU/ml }\end{array}$ & $\begin{array}{c}\% / \log \\
\text { Reduction }\end{array}$ & $\begin{array}{c}\mathrm{PC} \\
(\mathrm{CFU} / \mathrm{ml})\end{array}$ & $\begin{array}{l}\log 10 \\
\text { CFU/ml }\end{array}$ & $\begin{array}{c}\% / \log \\
\text { Reduction }\end{array}$ & $\begin{array}{c}\mathrm{PC} \\
(\mathrm{CFU} / \mathrm{ml})\end{array}$ & $\begin{array}{l}\log _{10} \\
\text { CFU/ml }\end{array}$ & $\begin{array}{c}\% / \log \\
\text { Reduction }\end{array}$ \\
\hline \multirow{6}{*}{$\mathrm{ECO} 1$} & 0 & $3.6 \times 10^{5}$ & 5.56 & NA / NA & $6.9 \times 10^{5}$ & 5.84 & $\mathrm{NA} / \mathrm{NA}$ & $3.9 \times 10^{5}$ & 5.59 & NA / NA \\
\hline & 6 & $7.2 \times 10^{4}$ & 4.86 & $80.00 / 0.70$ & $7.0 \times 10^{4}$ & 4.85 & $89.85 / 0.99$ & $2.4 \times 10^{4}$ & 4.38 & $93.85 / 1.21$ \\
\hline & 12 & $6.3 \times 10^{3}$ & 3.80 & $91.25 / 1.06$ & $2.4 \times 10^{3}$ & 3.38 & $96.57 / 1.47$ & $2.2 \times 10^{3}$ & 3.34 & $90.83 / 1.04$ \\
\hline & 18 & $2.0 \times 10^{2}$ & 2.30 & $96.83 / 1.50$ & $2.3 \times 10^{2}$ & 2.36 & $90.42 / 1.02$ & $1.7 \times 10^{2}$ & 3.23 & $92.27 / 0.11$ \\
\hline & 24 & NG & 0.0 & $\geq 99.9 / 2.30$ & $N G$ & 0.0 & $\geq 99.9 / 2.36$ & NG & 0.0 & $\geq 99.9 / 3.23$ \\
\hline & 30 & NG & 0.0 & $\geq 99.9 / 0.0$ & NG & 0.0 & $\geq 99.9 / 0.0$ & NG & 0.0 & $\geq 99.9 / 0.0$ \\
\hline \multirow{6}{*}{ ES02 } & 0 & $1.9 \times 10^{5}$ & 5.28 & $\mathrm{NA} / \mathrm{NA}$ & $2.4 \times 10^{5}$ & 5.38 & $\mathrm{NA} / \mathrm{NA}$ & $2.0 \times 10^{5}$ & 5.30 & $\mathrm{NA} / \mathrm{NA}$ \\
\hline & 6 & $1.7 \times 10^{4}$ & 4.23 & $91.05 / 1.05$ & $1.0 \times 10^{5}$ & 5.00 & $58.33 / 0.38$ & $2.4 \times 10^{4}$ & 4.38 & $88.00 / 0.92$ \\
\hline & 12 & $1.2 \times 10^{3}$ & 3.08 & $92.94 / 1.15$ & $1.5 \times 10^{4}$ & 4.18 & $85.00 / 0.82$ & $1.2 \times 10^{4}$ & 4.08 & $50.00 / 0.30$ \\
\hline & 18 & $2.4 \times 10^{2}$ & 2.38 & $80.00 / 0.70$ & $2.4 \times 10^{3}$ & 3.38 & $84.00 / 0.80$ & $3.6 \times 10^{3}$ & 3.56 & $70.00 / 0.52$ \\
\hline & 24 & $1.0 \times 10^{2}$ & 2.00 & $58.33 / 0.38$ & $1.2 \times 10^{2}$ & 2.08 & $95.00 / 1.30$ & $2.2 \times 10^{2}$ & 2.34 & $93.89 / 1.22$ \\
\hline & 30 & NG & 0.0 & $\geq 99.9 / 2.00$ & NG & 0.0 & $\geq 99.9 / 2.08$ & $1.0 \times 10^{2}$ & 2.00 & $54.55 / 0.34$ \\
\hline \multirow{6}{*}{ KPO2 } & 0 & $3.9 \times 10^{5}$ & 5.59 & $\mathrm{NA} / \mathrm{NA}$ & $3.9 \times 10^{5}$ & 5.59 & $\mathrm{NA} / \mathrm{NA}$ & $3.3 \times 10^{5}$ & 5.52 & NA / NA \\
\hline & 6 & $2.4 \times 10^{4}$ & 4.38 & $93.85 / 1.21$ & $2.4 \times 10^{4}$ & 4.38 & $93.85 / 1.21$ & $3.0 \times 10^{4}$ & 4.48 & $90.91 / 1.04$ \\
\hline & 12 & $1.2 \times 10^{3}$ & 3.08 & $95.00 / 1.30$ & $2.2 \times 10^{3}$ & 3.34 & $90.83 / 1.04$ & $1.0 \times 10^{3}$ & 3.00 & $96.67 / 1.48$ \\
\hline & 18 & $1.7 \times 10^{2}$ & 2.23 & $85.83 / 0.85$ & $1.7 \times 10^{2}$ & 2.23 & $92.27 / 1.02$ & NG & 0.0 & $\geq 99.9 / 3.00$ \\
\hline & 24 & $N G$ & 0.0 & $\geq 99.9 / 2.23$ & NG & 0.0 & $\geq 99.9 / 2.23$ & NG & 0.0 & $\geq 99.9 / 0.0$ \\
\hline & 30 & NG & 0.0 & $\geq 99.9 / 0.0$ & NG & 0.0 & $\geq 99.9 / 0.0$ & NG & 0.0 & $\geq 99.9 / 0.0$ \\
\hline \multirow{6}{*}{ PA01 } & 0 & $7.7 \times 10^{5}$ & 5.89 & $\mathrm{NA} / \mathrm{NA}$ & $2.0 \times 10^{5}$ & 5.30 & $\mathrm{NA} / \mathrm{NA}$ & $4.8 \times 10^{5}$ & 5.68 & NA / NA \\
\hline & 6 & $2.0 \times 10^{5}$ & 5.30 & $74.03 / 0.59$ & $1.4 \times 10^{4}$ & 4.15 & $93.00 / 1.15$ & $2.4 \times 10^{4}$ & 4.38 & $95.00 / 1.30$ \\
\hline & 12 & $1.2 \times 10^{4}$ & 4.08 & $94.00 / 1.22$ & $1.2 \times 10^{3}$ & 3.08 & $91.43 / 1.07$ & $1.0 \times 10^{3}$ & 3.00 & $95.83 / 1.38$ \\
\hline & 18 & $3.3 \times 10^{3}$ & 3.52 & $72.50 / 0.56$ & $3.6 \times 10^{2}$ & 2.56 & $70.00 / 0.52$ & $1.2 \times 10^{2}$ & 2.08 & $88.00 / 0.92$ \\
\hline & 24 & $2.0 \times 10^{2}$ & 2.30 & $93.94 / 1.22$ & $N G$ & 0.0 & $\geq 99.9 / 2.56$ & NG & 0.0 & $\geq 99.9 / 2.08$ \\
\hline & 30 & NG & 0.0 & $\geq 99.9 / 2.30$ & NG & 0.0 & $\geq 99.9 / 0.0$ & NG & 0.0 & $\geq 99.9 / 0.0$ \\
\hline
\end{tabular}

reduction in viable cell count of CoNS exposed to $\mathrm{AML}$ was $\geq 58.6 \%$ and $0.38 \log _{10} \mathrm{CFU} / \mathrm{ml}$ respectively. The log reduction in viable cell counts of S. aureus, Streptococcus spp and CoNS exposed to PRO for $30 \mathrm{hrs}$ ranged from 0.13 to $1.54 \log _{10} \mathrm{CFU} / \mathrm{ml}, 0.26$ to $2.08 \log _{10}$ $\mathrm{CFU} / \mathrm{ml}$ and 0.26 to $2.20 \quad \log _{10} \mathrm{CFU} / \mathrm{ml}$ respectively (Table 3 ). At 1 XMIC, THI achieved bactericidal effects on $S$. aureus, Streptococcus spp, E. coli, K. pneumoniae and $P$. aeruginosa at 24 hours post inoculation while $\geq 99.9 \%$ reduction in survival from the original inoculum was achieved for CoNS and Enterobacter spp at 30 hours post inoculation (Tables 3 and 4).

The ranges of log reduction in viable cell counts of GNB exposed to AML for $30 \mathrm{hrs}$ were $E$. coli $\left(0.7\right.$ to $\left.2.30 \log _{10} \mathrm{CFU} / \mathrm{ml}\right)$, Enterobacter spp (0.38 to $\left.2.0 \log _{10} \mathrm{CFU} / \mathrm{ml}\right)$, K. pneumoniae ( 0.85 to $2.23 \log _{10} \mathrm{CFU} / \mathrm{ml}$ ) and $P$. aeruginosa 0.56 to $2.3 \log _{10} \mathrm{CFU} / \mathrm{ml}$ ) (Table 4). The bactericidal activity of PRO on $K$. pneumoniae and $P$. aeruginosa was achieved at
18- and 30-hours post inoculation respectively whereas $1.0 \times 10^{2} \mathrm{CFU} / \mathrm{ml}$ Enterobacter spp were still viable at 30 hours post inoculation (Table 4). The time kill kinetics curves of AML, THI and PRO (1.0 x MIC) against the bacterial isolates are shown in Figs 1 and 2.

The increase in viable cell counts of the GPB and GNB not exposed to AML, THI and PRO within the 30 hours of incubation were observed and presented in Tables 5 and 6 . The viable cell count of $S$. aureus increased from 5.57 to $7.79 \log _{10} \mathrm{CFU} / \mathrm{ml}$, those of Streptococcus spp cells increased from 5.61 to 7.85 $\log _{10} \mathrm{CFU} / \mathrm{ml}$ while those of CoNS increased from 5.61 to $7.85 \log _{10} \mathrm{CFU} / \mathrm{ml}$ (Table 5). The increase in the viable cell count of GNB within the 30 hours incubation period was 5.60 to $7.84 \log _{10} \mathrm{CFU} / \mathrm{ml}$ for $E$ coli, 5.41 to 7.60 $\log _{10} \mathrm{CFU} / \mathrm{ml}$ for Enterobacter spp, 5.58 to 7.72 $\log _{10} \mathrm{CFU} / \mathrm{ml}$ for K. pneumoniae and 5.76 to $7.86 \log _{10} \mathrm{CFU} / \mathrm{ml}$ for $P$. aeruginosa (Table $6)$. 


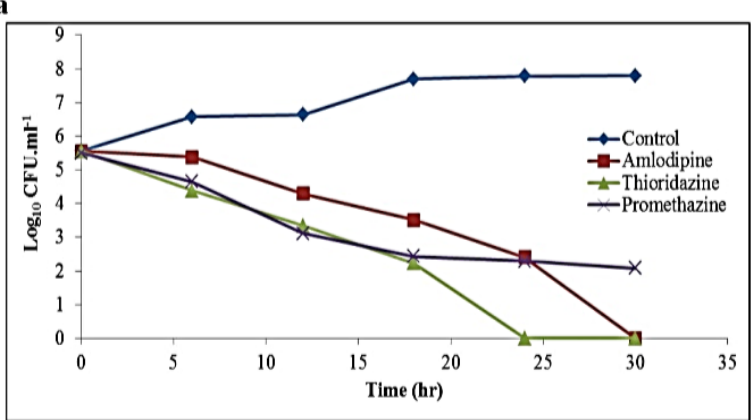

c

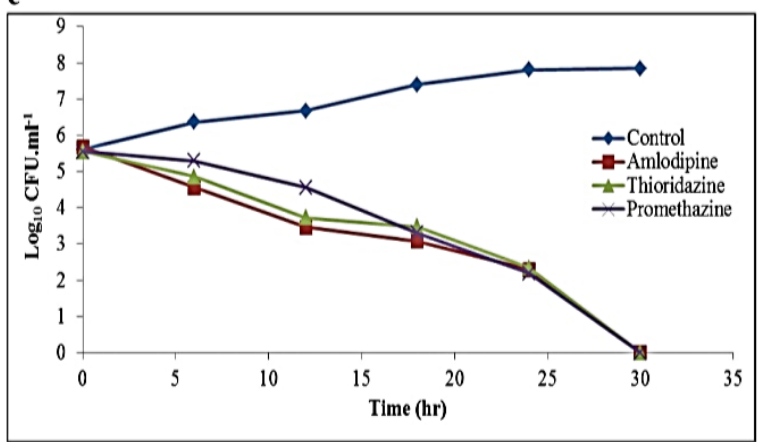

b

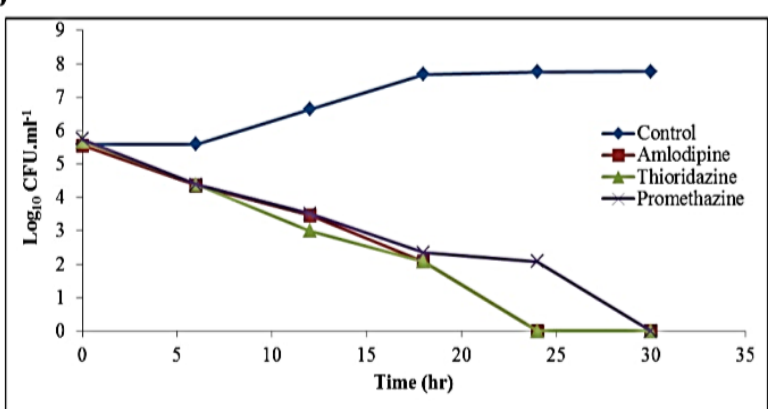

d

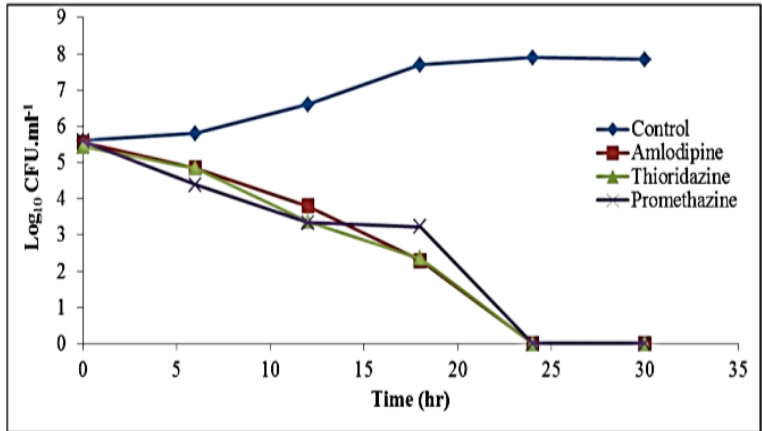

Fig 1: Time Kill Kinetics Curve of Amlodipine, Thioridazine and Promethazine (1 x MIC) and control against (a) S. aureus, (b) Streptococcus spp., (c) Coagulase negative staphylococci, (d) Escherichia coli
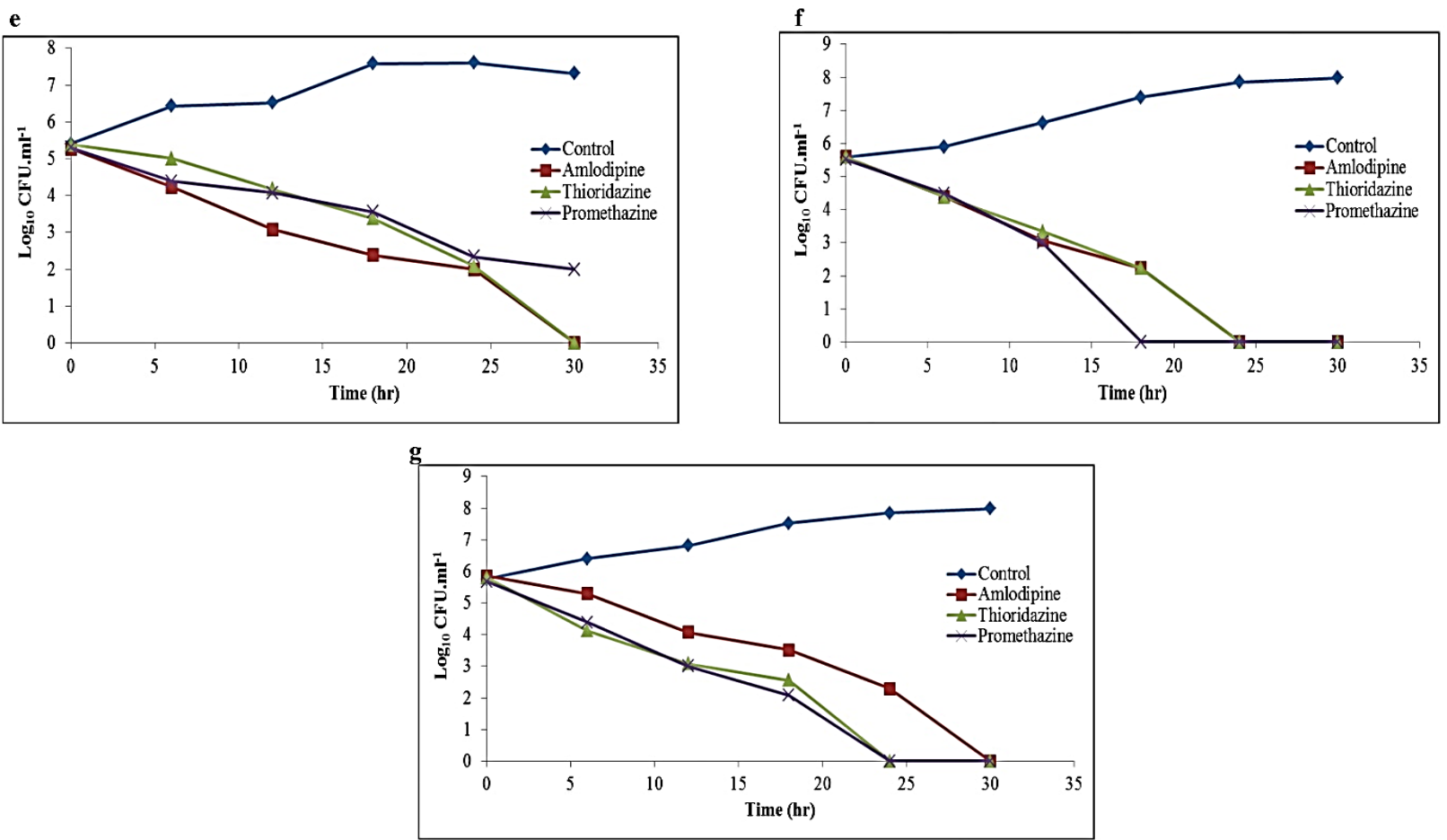

Fig 2: Time Kill Kinetics Curve of Amlodipine, Thioridazine, Promethazine $(1 \times \mathrm{MIC})$ and control against (e) Enterobacter spp., (f) Klebsiella pneumoniae, (g) Pseudomonas aeruginosa 
Table 5: Growth of Gram-positive bacterial cells unexposed to non-antibiotic drugs

\begin{tabular}{|c|c|c|c|c|}
\hline Bacterial Isolates & Codes & $\begin{array}{c}\text { Time Interval } \\
(\mathrm{Hr})\end{array}$ & $\begin{array}{l}\text { Plate Counts } \\
\text { (CFU/ml) }\end{array}$ & $\begin{array}{l}\mathrm{Log} 10 \\
\mathrm{CFU} / \mathrm{mI}\end{array}$ \\
\hline Staphylococcus aureus & SAO1 & $\begin{array}{c}0 \\
6 \\
12 \\
18 \\
24 \\
30 \\
\end{array}$ & $\begin{array}{l}3.7 \times 10^{5} \\
3.8 \times 10^{6} \\
4.4 \times 10^{6} \\
5.0 \times 10^{7} \\
6.1 \times 10^{7} \\
6.2 \times 10^{7} \\
\end{array}$ & $\begin{array}{l}5.57 \\
6.58 \\
6.64 \\
7.70 \\
7.78 \\
7.79 \\
\end{array}$ \\
\hline Streptococcus spp & $\mathrm{SSO} 2$ & $\begin{array}{r}0 \\
6 \\
12 \\
18 \\
24 \\
30 \\
\end{array}$ & $\begin{array}{l}3.9 \times 10^{5} \\
3.9 \times 10^{5} \\
4.4 \times 10^{6} \\
4.8 \times 10^{7} \\
5.7 \times 10^{7} \\
5.9 \times 10^{7} \\
\end{array}$ & $\begin{array}{l}5.59 \\
5.59 \\
6.64 \\
7.68 \\
7.76 \\
7.77 \\
\end{array}$ \\
\hline $\begin{array}{l}\text { Coagulase negative } \\
\text { Staphylococcus }\end{array}$ & $\mathrm{CSO} 2$ & $\begin{array}{l}0 \\
6 \\
12 \\
18 \\
24 \\
30 \\
\end{array}$ & $\begin{array}{l}4.1 \times 10^{5} \\
2.3 \times 10^{6} \\
4.7 \times 10^{6} \\
3.0 \times 10^{7} \\
6.4 \times 10^{5} \\
7.0 \times 10^{5} \\
\end{array}$ & $\begin{array}{l}5.61 \\
6.36 \\
6.67 \\
7.48 \\
7.81 \\
7.85 \\
\end{array}$ \\
\hline
\end{tabular}

Table 6: Growth of Gram-negative bacterial cells unexposed to non-antibiotic drugs

\begin{tabular}{|c|c|c|c|c|}
\hline Bacterial Isolates & Codes & $\begin{array}{c}\text { Time Interval } \\
(\mathrm{Hr})\end{array}$ & $\begin{array}{c}\text { Plate Counts } \\
(\mathrm{CFU} / \mathrm{ml})\end{array}$ & $\begin{array}{l}\log 10 \\
\mathrm{CFU} / \mathrm{ml}\end{array}$ \\
\hline Escherichia coli & EC01 & $\begin{array}{c}0 \\
6 \\
12 \\
18 \\
24 \\
30\end{array}$ & $\begin{array}{l}4.0 \times 10^{5} \\
6.6 \times 10^{5} \\
4.1 \times 10^{6} \\
5.5 \times 10^{7} \\
7.9 \times 10^{7} \\
6.9 \times 10^{7}\end{array}$ & $\begin{array}{l}5.60 \\
5.82 \\
6.61 \\
7.74 \\
7.90 \\
7.84\end{array}$ \\
\hline Enterobacter spp & ESO2 & $\begin{array}{c}0 \\
6 \\
12 \\
18 \\
24 \\
30\end{array}$ & $\begin{array}{l}2.6 \times 10^{5} \\
2.7 \times 10^{6} \\
3.3 \times 10^{6} \\
3.8 \times 10^{6} \\
4.3 \times 10^{7} \\
4.0 \times 10^{7}\end{array}$ & $\begin{array}{l}5.41 \\
6.43 \\
6.52 \\
6.58 \\
7.63 \\
7.60\end{array}$ \\
\hline Klebsiella pneumoniae & KPO2 & $\begin{array}{c}0 \\
6 \\
12 \\
18 \\
24 \\
30\end{array}$ & $\begin{array}{l}3.8 \times 10^{5} \\
1.0 \times 10^{6} \\
4.3 \times 10^{6} \\
4.9 \times 10^{7} \\
5.1 \times 10^{7} \\
5.3 \times 10^{7}\end{array}$ & $\begin{array}{l}5.58 \\
6.00 \\
6.63 \\
7.69 \\
7.71 \\
7.72 \\
\end{array}$ \\
\hline Pseudomonas aeruginosa & PA01 & $\begin{array}{c}0 \\
6 \\
12 \\
18 \\
24 \\
30\end{array}$ & $\begin{array}{l}5.8 \times 10^{5} \\
6.0 \times 10^{6} \\
6.4 \times 10^{6} \\
6.9 \times 10^{7} \\
7.1 \times 10^{7} \\
7.3 \times 10^{7}\end{array}$ & $\begin{array}{l}5.76 \\
6.78 \\
6.81 \\
7.82 \\
7.85 \\
7.86\end{array}$ \\
\hline
\end{tabular}

\section{Discussion:}

The global emergence of multi-drug resistant pathogens as well as the continuing challenge of infectious diseases have necessitated the scientific exploration of novel, potent and affordable antimicrobial agents such as medicinal plants (5) and non-antibiotic drugs (6) in the management of infectious diseases. In this study, amlodipine (AML) demonstrated higher growth inhibitory activities at $5 \mathrm{mg} / \mathrm{ml}$

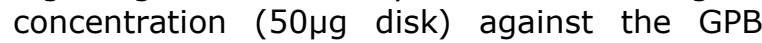
(S. aureus, CoNS, Streptococcus spp) and GNB (E. coli, Enterobacter spp, K. pneumoniae and $P$. aeruginosa) than at $2.5 \mathrm{mg} / \mathrm{ml}$ concentration $(25 \mu \mathrm{g})$, indicating a concentration-dependent inhibition of bacterial growth.

The antibacterial activity of AML in this study substantiates the findings of Kumar et al., (8) that AML, a calcium channel blocker and cardiovascular drug, exhibited antibacterial activities against $S$. aureus, $E$. coli and $P$. aeruginosa. The antibacterial activities of AML on both GPB and GNB indicated its broadspectrum activity and these findings concurs with the reports of Mazumdar et al., (17) and Pereira et al., (18), which reported broadspectrum antibacterial activities of AML. The pattern of time-kill kinetics, investigated by the microbroth kinetic growth assay, against the GPB and GNB showed that AML exhibited bactericidal activities ( $\geq 99.9 \%$ reduction in 
survival from the original inoculum) within 30 hours of exposure against the bacteria. These bactericidal activities of AML against the isolates in this study confirmed the findings previously reported by Kumar et al., (8) and Mazumdar et al., (17).

The MBC values of THI for the isolates ranged between 25 and $100 \mu \mathrm{g} / \mathrm{ml}$ with bactericidal effects on $S$. aureus, Streptococcus spp, $E$. coli, $K$. pneumoniae and $P$. aeruginosa at $\leq 24$ hours post inoculation. The antibacterial activities of THI on GPB and GNB in this study corroborates the findings of Radhakrishnan et al., (19) on the potentiality of THI as an effective antibacterial agent. Our findings on antibacterial efficacy of THI on $P$. aeruginosa was also in conformity with a previous study by Mukherjee et al., (20), who reported that THI, an anti-psychotic drug, was a highly promising agent in the treatment of acute infections caused by $P$. aeruginosa. Studies have shown that THI exerts a bactericidal effect on bacteria by damaging the cell wall and causing major changes in expression of many genes involved in peptidoglycan biosynthesis (21). THI has also been reported to reverse antibiotic resistance by facilitating the elimination of resistance $(R)$ plasmid from MDR bacteria $(14,19)$.

In this study, PRO also exhibited antibacterial activities on both GPB and GNB, with log reduction in viable cell counts of GPB exposed for 30 hours ranging from 0.13 to $2.20 \log _{10} \mathrm{CFU} / \mathrm{ml}$. Our finding substantiates the reports of Dasgupta et al., (22) on antibacterial activity of PRO against antibiotic resistant bacterial isolates. Bactericidal activity of PRO against $S$. aureus in our study also agrees with the findings of Dastidar et al., (23). PRO, a phenothiazine, acts by inhibiting the efflux pump that protects bacterial cell against harmful chemical substances (24), and also affects energy sources, adenosine triphosphatase (ATPase), and genes that regulate permeability in bacteria (25). The increased permeability ensures that PRO molecules get to the DNA sites, intercalate between the bases, and consequently hinder the DNA transcription and translation processes (26). It has also been reported that PRO can reverse the phenotypes of MDR bacteria (14).

\section{Conclusion:}

Our study demonstrated in vitro antimicrobial efficacies and time kill kinetics of amlodipine, thioridazine and promethazine against pathogenic clinical bacterial isolates, which indicates that these non-antibiotic drugs may be useful therapeutic alternatives in the bid to reduce the burden of infectious diseases associated with antibiotic resistant pathogens. Consequent upon these findings, in vivo antibacterial studies of these non-antibiotic drugs are required.

\section{Authors' contributions:}

AOJ and SGI designed the study, wrote the protocol and first draft of the manuscript. UAN and AMF wrote part of the manuscript and managed the analyses of the study. AOJ and OGO managed the literature searches and performed the statistical analysis. All authors read and approved the final manuscript.

\section{References:}

1. Blondeau, J. M., and Tillotson, G. S. Antimicrobial susceptibility patterns of respiratory pathogens-a global perspective. Semin Respir Infect. 2000; 15: $195-200$.

2. Akinjogunla, O. J., Odeyemi, A. T., and Olasehinde, G. I. Epidemiological studies of urinary tract infections among post-menopausal women in Uyo, South-South, Nigeria. J A Sci. 2010; 6 (12): 1674-1681.

3. Levy, S. B. Active efflux, a common mechanism for biocide and antibiotic resistance. J Appl Microbiol. 2002; 92 Suppl: 65S-71S.

4. Akinjogunla, O. J., Eghafona, N. O., and Enabulele, I. O. Aetiologic agents of acute otitis media (AOM): prevalence, antibiotic susceptibility, $\beta$-lactamase and extended spectrum $\beta$-lactamase (ESßL) production. JMBFS. 2011; 1 (3): 333-353.

5. Akinjogunla, O. J., Adenugba, I. T., and Jumbo, O. M. In-vitro antibacterial evaluation of ethanolic stem crude extracts of Anacardium occidentale Linn. (Anacardiaceae) on $S$. mutans associated with dental caries. Sci J Microbiol. 2012; 1 (3): $71-81$.

6. Kruszewska, H., Zareba, T., and Tyski, S. Search of antimicrobial activity of selected non-antibiotic drugs. Acta Pol Pharm. 2002; 59 (6): 436-439

7. Kristiansen, J. E. The antimicrobial activity of nonantibiotics. Report from a congress on the antimicrobial effect of drugs other than antibiotics on bacteria, viruses, protozoa and other organisms. APMIS Suppl. 1992; 30: 7-14.

8. Kumar, K. A., Mazumdar, K., Dutta, N. K., et al. Evaluation of synergism between the aminoglycoside antibiotic streptomycin and the cardiovascular agent amlodipine. Biol Pharm Bull. 2004; 27: 1116 - 1120.

9. Annadurai, S., Basu, S., Ray, S., et al. Antimicrobial activity of the anti-inflammatory agent diclofenac sodium. Indian J Exp Biol. 1998; 36: 86-90.

10. Perlmutter, J. I., Forbes, L. T., Krysan, D. J., et al. Repurposing the antihistamine terfenadine for antimicrobial activity against $S$. aureus. J Med Chem. 2004; 20: 8054-8060. 
11. Munoz-Bellido, J. L., Munoz-Criado, S., and GraciaRodrıguez, J. A. Antimicrobial activity of psychotropic drugs selective serotonin reuptake inhibitors. Int J Antimicrob Agents. 2000; 14: 177-180.

12. Sweetman, S. C. Martindale, the complete drug reference. 33rd ed. Pharmaceutical Press, London, 2002: 1000-1254.

13. Skidgel, R. A., and Erdos, E. G. Histamine, bradykinin, and their antagonists. In: Brunton, L., Lazo, J., and Parker, K. (eds). Goodman and Gilman's the Pharmacological Bases of Therapeutics. McGraw-Hill Medical Publishing Division, New York, 2006: 629-652.

14. Amaral, L., Viveiros, M., and Kristiansen, J. E. Non-Antibiotics: Alternative therapy for the management of MDRTB and MRSA in economically disadvantaged countries. Curr Drug Targets. 2006; 7 (7): 887-891.

15. Cheesbrough, M. District Laboratory Practice in Tropical Countries (Part II). Cambridge University Press, 2006: 19-110.

16. Somchit, M. N., Mutalib, A. R., Ahmad, Z., et al. In vitro Antifungal Activity of Cassia tora L. J Trop Med Plants. 2004; 5 (1): 15-20.

17. Mazumdar, K., Kumar, K. A., and Dutta, N. K. Potential role of the cardiovascular nonantibiotic (helper compound) amlodipine in the treatment of microbial infections: scope and hope for the future. Int J Antimicrob Agents. 2010; 36: 295-302.

18. Pereira, M. R., Henrich, P. P., Sidhu, A. B., et al. In vivo and in vitro antimalarial properties of azithromycin-chloroquine combinations that include the resistance reversal agent amlodipine. Antimicrob Agents Chemother. 2011; 55: 31153124.
19. Radhakrishnan, V., Ganguly, K., Ganguly, M., et al Potentiality of tricyclic compound thioridazine as an effective antibacterial and anti-plasmid agent. Indian J Exp Biol. 1999; 37: 671-675.

20. Mukherjee, S., Chaki, S., Barman, S., et al. Effective elimination of drug resistance genes in pathogenic Pseudomonas aeruginosa by antipsychotic agent thioridazine. Curr Res Bacteriol. 2012; 5: 36-41.

21. Thorsing, M., Klitgaard, J. K., Atilano, M. L., et al. Thioridazine induces major changes in global gene expression and cell wall composition in methicillinresistant Staphylococcus aureus USA300. PLoS One. 2013; 8: e64518.

22. Dasgupta, A., Jeyaseeli., Dutta, N. K., et al. Studies on the antimicrobial potential of the cardiovascular drug lacidipine. In Vivo. 2007; 21 : 847-850.

23. Dastidar, S. G., Kristiansen, J. E., Molnar, J., et al. Role of phenothiazines and structurally similarly compounds of plant origin in the fight against infections by drug resistant bacteria. Antibiotics (Basel). 2013: 18 (1): 58-72.

24. Sharma, S., and Singh, A. Phenothiazines as antitubercular agents: mechanistic insights and clinical implications. J Expert Opin Invest Drugs. $2011 ; 12: 1-8$.

25. Sujata, G., Dastidar, J. E., Kristiansen, J. M., et al. Role of phenothiazines and structurally similar compounds of plant origin in the fight against infections by drug resistant bacteria. Antibiotics (Basel). 2013; 2 (1): 58-72.

26. Kristiansen, M. M., Leandro, C., Ordway, D., et al. Phenothiazine salter resistance of methicillin-resistant strains of Staphylococcus aureus (MRSA) to oxacillin in vitro. Int J Antimicrob Agents. 2003; 22 (3): 250-253. 